\title{
IFAS Community Development: Identifying Local Power Structures, The Social Participation/Social Activity Approach 1
}

\section{M.A. Brennan ${ }^{2}$}

This paper is part of a series of discussions on community development. This series includes specialized papers on leadership development, civic engagement, community action, and other topics important to the development of community.

\section{Introduction}

In the process of community development, it is important to identify positions, organizations, and individuals of power. All types of power can serve as a source of empowerment for local collective action or in more negative settings as a significant obstacle to the emergence of community agency, or the capacity for local of communities to act (Hyman, et al., 2001; Brennan, 2006). There are several ways that extension and other change agents can identify these power structures. One useful method is the social participation or social activity approach (herein referred to as the social participation approach).

\section{The Social Participation Approach}

A fourth and final method for identifying community power structures is the social participation approach. Utilizing this approach, participants active in voluntary associations in the community are identified. These include those holding formal offices, but also activists, religious representatives, and others who actively participate in community activities.

\section{Assumptions of the Social Participation Approach}

This method of identifying power holders is based on the assumption that the power to shape community decisions is acquired through the active participation, holding of offices, or involvement in a communitys voluntary associations. These organizations are seen as providing the majority of services and decisions that impact the daily lives of residents.

1. This document is FCS 9259, one of a series of the Family Youth and Community Sciences Department, Florida Cooperative Extension Service, Institute of Food and Agricultural Sciences, University of Florida. Original publication date July 18, 2006. Visit the EDIS Web Site at http://edis.ifas.ufl.edu.

2. M. A. Brennan, assistant professor, Department of Family, Youth and Community Sciences, Cooperative Extension Service, Institute of Food and Agricultural Sciences, University of Florida, Gainesville, FL, 32611.

The Institute of Food and Agricultural Sciences (IFAS) is an Equal Opportunity Institution authorized to provide research, educational information and other services only to individuals and institutions that function with non-discrimination with respect to race, creed, color, religion, age, disability, sex, sexual orientation, marital status, national origin, political opinions or affiliations. U.S. Department of Agriculture, Cooperative Extension Service, University of Florida, IFAS, Florida A. \& M. University Cooperative Extension Program, and Boards of County Commissioners Cooperating. Larry Arrington, Dean 


\section{Procedures for Identifying Social Participation Power}

To identify leaders and power holders through this method, a series of steps can be taken. Included are:

1. Identify organizations dedicated to community service, community development, or other social support functions on which you are focusing. This can be done through a review of telephone books, directories, or Internet listings;

2. Identify lists of membership, officers, board of directors, and committees of each key association. These are most often publicly accessible in print or electronic formats through the Internet or by contacting the organization directly;

3. Determine overlap and assign weights to different positions (membership vs. committee; member vs. committee; chair vs. officer). It is likely that power holders will be present on more than one organizations board of directors, and may hold similar positions in each (i.e., chairperson or officer); and

4. Determine individuals who are active with the most organizations and have the more important positions within these organizations. These are key power holders.

\section{Types of leaders identified}

Utilizing this method, visible participants in various activities of voluntary associations are identified. These generally reflect individuals who are highly involved in multiple organizations, therefore shaping policy and decision making at several levels.

\section{Advantages and Disadvantages of this Method}

As with all methods for assessing local power, this method has distinct advantages and disadvantages. Among the advantages to consider when using this method are:
1. This method identifies activists whom are often difficult to identify using other methods;

2. It identifies future leaders in that younger people often join organizations to get involved in community affairs prior to achieving any formal power broker roles; and

3. This method identifies community members who are likely participating in various stages and action phases of community issues.

4. Correspondingly some of the disadvantages of this method are:

5. This method can be time consuming and costly;

6. It tends to identify only highly visible activists and not behind the scenes players; and

7. This method fails to identify the motivations or special issues by which very active individuals become involved.

\section{References and Suggested Reading}

Brennan, M. A. (2006). Identifying Local Power Structures to Facilitate Leadership and Community Development. Gainesville, FL:

Cooperative Extension Service, Institute of Food and Agricultural Sciences, University of Florida. EDIS. Publication number: FCS 9238/FY816.

Boulding, K. (1989). The Three Faces of Power. Sage Publications.

Hyman, D., J. McKnight, and F. Higdon. (2001). Doing Democracy: Conflict and Consensus Strategies for Citizens, Organizations, and Communities. Erudition Press. 